\title{
Dynamics of COVID-19 in Nigeria; Prevention of Likely Third Wave of the Deadly Pandemics
}

\author{
Adebisi Sunday Adesina \\ Faculty of Science, Department of Mathematics, University of Lagos, Akoka, Yaba, Nigeria \\ Email address: \\ adesinasunday@yahoo.com

\section{To cite this article:} \\ Adebisi Sunday Adesina. Dynamics of COVID-19 in Nigeria; Prevention of Likely Third Wave of the Deadly Pandemics. International \\ Journal of Discrete Mathematics. Vol. 6, No. 1, 2021, pp. 1-4. doi: 10.11648/j.dmath.20210601.11
}

Received: April 14, 2021; Accepted: May 3, 2021; Published: May 14, 2021

\begin{abstract}
The rate through which the newly discovered coronavirus otherwise referred to as covid-19 is spreading seems to be very alarming and therefore calls for immediate and proper attention in order to forestall ugly occurrences and experience of deteriorate in the health of the majority of people in the country. Of recent, reports are showing that the impact of the third wave is already showing in some vulnerable places. The rate of the spread of this deadly and threatening pandemic in almost every nook and cranny of the country, most especially the highly populated cities and towns, seems to be spontaneous and exponential sort of. Hence, as a result, decisive measures and provision need to be put in place so as to not to make the situation more disastrous. From observations so far, it was gathered that the numbers recorded during week days is relatively far more when compared with the number of occurrence during weekends such as Fridays as well as Saturdays. Hence this observations calls for immediate attention. This work considers the sudden numerical growths in the actual number of the casualties (otherwise called the first and the second waves) which occur intermittently, the statistical implications and recommendations for a better and saver live for the populace.
\end{abstract}

Keywords: COVID-19, Dynamics, Chaos, Pandemics, Mental Health, Transmission, Prevention

\section{Introduction}

It is no more a news that the second wave of covd-19 spreads it like the wild fire. Of recent, the reports have it that the mortality rate has actually outgrown the number of the war casualties during the second world war in the United State of America. The rate seems to be spontaneous and exponential sort of. Hence, as a result, decisive measures and provision need to be put in place so as to not to make the situation more disastrous. In this paper, the situation is considered from the statistical point of view so as to put a lasting solution to the situation [20,21].

Among the first countries in Sub-Saharan Africa to identify COVID-19 (coronavirus) cases Nigeria and has since implemented strict measures to contain the spread of the virus. This has great impacts and implication on the economy of the nation by and large.

The simultaneous challenge of combating the public health crisis of the pandemic alongside trying to bolster a weakening economy is presently being confronted by the federal government. Given the mounting evidence that the social and economic impacts of these twin crises are likely to be significant, the government is ramping up policy interventions that can help mitigate such negative and seeming chaos impacts $[18,19]$. Alleviating the impacts of the COVID-19 crisis is vital for preventing poverty from deepening and increasing in Nigeria; before the crisis, approximately 4 in 10 Nigerians were living below the national poverty line, and millions more were living just above the poverty line, making them vulnerable to falling back into poverty when shocks occur $[1,2]$.

For a measure to provide the government with timely evidence to guide the policy response, a new high-frequency survey - the Nigeria COVID-19 National Longitudinal Phone Survey (COVID-19 NLPS) - has been initiated in Nigeria. This survey is being implemented by the National Bureau of Statistics with technical support from the World Bank and is designed to measure and monitor the economic and social impacts of the COVID-19 crisis by tracking households' welfare and behavior every month over a period of 12 months. The survey has a panel structure, such that it follows a representative sample of Nigerian households to 
assess how key indicators that may underpin the overall policy response are changing over time [3-6].

\section{Monitoring Survey of the Household COVID-19}

The COVID-19 NLPS collects a wide range of information from households across Nigeria. The sample, which is nationally representative and covers both urban and rural areas, was drawn from the 2018/19 General Household Survey Panel (GHS-Panel), so vital background information on each household was already available. The survey covers important topics including knowledge and concerns about the pandemic, access to food and other basic needs, employment and income loss, and safety nets and coping strategies. Its design is flexible, such that the topics covered can be altered according to evolving needs, priorities, and insights from emerging data. The survey is implemented using the Survey Solutions software for Computer Assisted Telephone Interviewing, this allows for faster access to the data and dissemination of results.

Coronaviruses are a large family of viruses that cause not only the common cold but also more serious respiratory illnesses. A novel coronavirus (2019-Ncov) was identified as the source of the illnesses on January 7, with the infection first reported in a Wuhan seafood market that also sold live animals. The death toll has exceeded 100 and the number of infected cases exceeds 4500. The world is one huge global village and China is Africa's biggest trading partner so Nigeria is understandably concerned. The Nigerian government says health authorities at points of entry are on alert for cases of coronavirus arriving in Africa's most populous country. The Nigeria Center for Disease Control (NCDC) has asked travelers coming from Wuhan to report to a medical facility and the center if they feel ill [18-21].

Transmission through direct contact with infected animals coughing and sneezing contact directly with infected people or things they've touched. Part of the symptoms includes Fever Difficulty breathing Sore throat Runny nose Severe cough Pneumonia which in many cases leads to death. Most victims die from complications including pneumonia and from swelling in the lungs. Severe Pneumonia can kill by causing the individual to drown in the fluid flooding their lungs. In the case of swelling of the lungs, the swelling makes it hard for the lungs to pass oxygen into the bloodstream, this leads to organ failure and death. The practice of the same prevention tips for a common cold can be applied. Wash your hands regularly with soap and warm water. Cover your mouth and nose properly with a facemasks face shield, handkerchief, tissue paper or your elbow when sneezing and/or coughing. Avoid direct close contact with anyone showing symptoms Keep hydrated. Use alcoholbased hand sanitizer. Get plenty of rest. Avoid selfmedication, Report to medical officials is needed for necessary facility. If you have symptoms, please do these: there is the need to stay home except to get medical care.
Separate self from other people in your home. As much as possible, need to stay in a different room from other people in your home. Also, you should use a separate bathroom, if available. Calling ahead before visiting health personnel and doctor is very necessary. Before medical appointment, calling should be made to the healthcare provider and tell them your symptoms and fears for a 2019-nCoV infection. This will help the healthcare provider's office take steps to keep other people from getting infected. Symptoms need be checked. Seek prompt medical attention if your illness is worsening (e.g., difficulty breathing). Is there a cure for the virus? Not yet. Since the start of the pandemic, different drugs have had different success rates in clinical trials focused on treating the virus. It is important to remember that this is a new virus, hence it will take a while to find a definitive cure. The NCDC says that current treatment is targeted at relieving symptoms while the immune system fights the illness. Will lime and ginger protect me from the virus? No. Fruits and other natural spices can help boost your immune system but they will not protect you from getting the virus. Even as you endeavor to fortify your immunity, it is more important to follow the guidelines and stay safe this season.

The National Center for Disease Control (NCDC) reported a record high of 930 and 459 new cases on the 16th and 17th of December. The much talked about 'second wave' is upon us $[20,21]$.

There is a steadily rising in the affecting numbers and even surpassing previous levels both in new cases and deaths. This has led to new restrictions or even lockdowns. Health workers are struggling to cope with the impact of the coronavirus crisis, suffering severe mental health problems such as panic attacks and having sleepless nights, new research suggests. Almost half of 14,000 health employees including nurses, porters, paramedics, healthcare assistants and staff surveyed by the union said they have struggled to cope.

\section{Reason for the Resurgence}

The reasons for this include but are not restricted to;

(i). The weather; globally temperatures are dropping so more people will tend towards staying indoors or in enclosed spaces.

(ii). The time of the year; is characterized by families, religious and corporate bodies congregating to celebrate the end of the year and of course Christmas.

(iii). COVID-19 fatigue; most people are tired of all the restrictions that have been placed on social activities. This has led a lot of people to flout the guidelines.

(iv). The cyclical nature of epidemics; right from the moment we got off the plateau of the first wave, experts predicted a second wave, citing the first two reasons as the motivating factors.

Thankfully, a number of pharmaceutical companies have manufactured and published highly effective vaccine results. These are yet to be approved for distribution in Nigeria.

The coronavirus disease is highly intimidating and the 
spread is negatively impacting nations around the world. National borders are closed, the economy is shut down, and self-quarantining of millions of people have become the "new normal."

Results have actually shown that half have sought mental health support, with the majority turning to friends, family and colleagues.

A lot of individuals are exhausted with no let-up in sight given the increase in hospital admissions and backlog of cancelled treatments. Others are traumatized from seeing patients die before their time - no one can comprehend the toll this has taken.

An health department of Health and Social Care spokeswoman said: "A dedicated 24/7 support service is already available to front line staff, and the NHS has invested $£ 15$ million to provide dedicated mental health support, alongside practical and financial advice, and develop a national support service for critical care staff who are most vulnerable to severe trauma plus a host of other support options [7-17].

In order to make your environment safer, Avoid the 3Cs: spaces that are closed, crowded or involve close contact. Outbreaks have been reported in restaurants, choir practices, fitness classes, nightclubs, offices and places of worship where people have gathered, often in crowded indoor settings where they talk loudly, shout, breathe heavily or sing. The risks of getting COVID-19 are higher in crowded and inadequately ventilated spaces where infected people spend long periods of time together in close proximity. These environments are where the virus appears to spread by respiratory droplets or aerosols more efficiently, so taking precautions is even more important.

\section{Data and the Statistical Analysis}

The following information was obtained recently, indicating the level of spread of the deadly disease, recently. Each of the first rows indicates the day of occurrence while the second row states the number infected for each of the days.

Table 1. Statistical Data.

\begin{tabular}{|c|c|c|c|c|c|c|c|c|c|c|c|c|c|c|c|c|c|c|c|}
\hline $\begin{array}{l}\text { April 1 } \\
85 \\
\end{array}$ & & $\begin{array}{l}\text { April } 24 \\
14\end{array}$ & $\begin{array}{l}29 \\
196 \\
\end{array}$ & $\begin{array}{l}\text { May } \\
218\end{array}$ & & $\begin{array}{l}6 \\
195 \\
\end{array}$ & $\begin{array}{l}9 \\
239 \\
\end{array}$ & & $\begin{array}{l}11 \\
242 \\
\end{array}$ & $\begin{array}{l}14 \\
191 \\
\end{array}$ & $\begin{array}{l}16 \\
11 \\
\end{array}$ & & $\begin{array}{l}17 \\
338 \\
\end{array}$ & $\begin{array}{l}18 \\
21\end{array}$ & $\begin{array}{l}2 \\
3 \\
\end{array}$ & $\begin{array}{l}23 \\
26 \\
\end{array}$ & $\begin{array}{l}25 \\
22 \\
\end{array}$ & $\begin{array}{l}26 \\
27 \\
\end{array}$ & $\begin{array}{l}27 \\
389 \\
\end{array}$ \\
\hline $\begin{array}{l}29 \\
387 \\
\end{array}$ & $\begin{array}{l}30 \\
553 \\
\end{array}$ & $\begin{array}{l}31 \\
307 \\
\end{array}$ & $\begin{array}{l}\text { June } 2 \\
241 \\
\end{array}$ & $\begin{array}{l}3 \\
34 \\
\end{array}$ & & $\begin{array}{l}4 \\
350 \\
\end{array}$ & $\begin{array}{l}5 \\
328 \\
\end{array}$ & & $\begin{array}{l}9 \\
663 \\
\end{array}$ & $\begin{array}{l}8 \\
315 \\
\end{array}$ & & $\begin{array}{l}9 \\
216 \\
\end{array}$ & & $\begin{array}{l}10 \\
409\end{array}$ & $\begin{array}{l}11 \\
681\end{array}$ & $\begin{array}{l}12 \\
627 \\
\end{array}$ & $\begin{array}{l}13 \\
501 \\
\end{array}$ & $\begin{array}{l}14 \\
403 \\
\end{array}$ & $\begin{array}{l}15 \\
573 \\
\end{array}$ \\
\hline $\begin{array}{l}16 \\
490 \\
\end{array}$ & $\begin{array}{l}18 \\
745 \\
\end{array}$ & $\begin{array}{l}29 \\
196 \\
\end{array}$ & $\begin{array}{l}24 \\
649 \\
\end{array}$ & $\begin{array}{l}25 \\
594 \\
\end{array}$ & $\begin{array}{l}27 \\
779 \\
\end{array}$ & & & $\begin{array}{l}29 \\
566 \\
\end{array}$ & $\begin{array}{l}30 \\
561 \\
\end{array}$ & & $\begin{array}{l}\text { July } 1 \\
790 \\
\end{array}$ & & $\begin{array}{l}2 \\
626 \\
\end{array}$ & & $\begin{array}{l}4 \\
603 \\
\end{array}$ & $\begin{array}{l}6 \\
575 \\
\end{array}$ & $\begin{array}{l}7 \\
503 \\
\end{array}$ & $\begin{array}{l}9 \\
499 \\
\end{array}$ & $\begin{array}{l}11 \\
664 \\
\end{array}$ \\
\hline $\begin{array}{l}15 \\
643 \\
\end{array}$ & $\begin{array}{l}16 \\
595 \\
\end{array}$ & $\begin{array}{l}18 \\
653 \\
\end{array}$ & $\begin{array}{l}19 \\
556\end{array}$ & $\begin{array}{l}20 \\
56 \\
\end{array}$ & & $\begin{array}{l}21 \\
576 \\
\end{array}$ & $\begin{array}{l}23 \\
604\end{array}$ & & $\begin{array}{l}24 \\
591 \\
\end{array}$ & $\begin{array}{l}26 \\
555\end{array}$ & & $\begin{array}{l}28 \\
624 \\
\end{array}$ & $\begin{array}{l}2 \\
4 \\
\end{array}$ & 29 & $\begin{array}{l}31 \\
462 \\
\end{array}$ & $\begin{array}{l}\text { Aug. } 5 \\
457\end{array}$ & $\begin{array}{l}6 \\
354 \\
\end{array}$ & $\begin{array}{l}9 \\
437 \\
\end{array}$ & $\begin{array}{l}12 \\
453 \\
\end{array}$ \\
\hline 14 & & & 17 & & & 20 & & & 22 & & & & 24 & & & 27 & & 30 & \\
\hline 327 & & & 417 & & & 476 & & & 601 & & & & 321 & & & 296 & & 138 & \\
\hline
\end{tabular}

Table 2. Second wave.

\begin{tabular}{|c|c|c|c|c|c|c|c|c|c|c|c|c|c|c|c|c|}
\hline Dec. 3 & 7 & 8 & 10 & 11 & 15 & 16 & 17 & & 18 & 19 & 22 & 23 & 24 & \multirow{2}{*}{\multicolumn{2}{|c|}{$\begin{array}{l}26 \\
829 \\
\end{array}$}} & \multirow{2}{*}{$\begin{array}{l}30 \\
1016\end{array}$} \\
\hline 343 & 390 & 550 & 675 & 796 & 758 & 930 & 1145 & & 806 & 920 & 999 & 1133 & 1041 & & & \\
\hline 31 & \multicolumn{2}{|c|}{ Jan. 1} & 3 & 4 & 5 & 6 & 8 & 9 & 10 & 12 & 14 & 15 & 16 & 17 & 18 & 19 \\
\hline 1031 & \multicolumn{2}{|c|}{980} & 917 & 1271 & 1354 & 1664 & 1544 & 1585 & 1024 & 1270 & 1479 & 1867 & 1598 & 1444 & 1617 & 1301 \\
\hline 20 & 21 & 23 & 24 & 25 & 27 & 28 & 29 & & 31 & Feb. 1 & & & & & & \\
\hline 1386 & 1964 & 2464 & 964 & 1430 & 1861 & 864 & 1883 & & 685 & 676 & & & & & & \\
\hline
\end{tabular}

Transforming these, we have as follows :

Table 3. Transformation of Table 1 (per two weeks).

\begin{tabular}{llllllll}
\hline April week 3-4 & May week 1-2 & $\begin{array}{l}\text { May week } \\
\mathbf{3 - 4}\end{array}$ & $\begin{array}{l}\text { June week 1- } \\
\mathbf{2}\end{array}$ & $\begin{array}{l}\text { June week 3- } \\
\mathbf{4}\end{array}$ & $\begin{array}{l}\text { July week 1- } \\
\mathbf{2}\end{array}$ & $\begin{array}{l}\text { July week 3- } \\
\mathbf{4}\end{array}$ & $\begin{array}{l}\text { Aug. week } \\
\mathbf{1 - 2}\end{array}$ \\
\hline X 395 & 1085 & 3470 & 4865 & 5447 & 4260 & 6825 \\
\hline
\end{tabular}

$$
\operatorname{Mean}_{(\mathrm{A})}=\frac{\sum X}{n}=\frac{30,626}{9 \times 2 \times 7}=243 \text { per day. }
$$

And for the Second wave we have as follows: 
Table 4. Transformation of Table 2: Second wave (per two weeks).

\begin{tabular}{|c|c|c|c|c|c|c|c|c|c|c|}
\hline $\begin{array}{l}\text { Dec. } \\
\text { week1 }\end{array}$ & $\begin{array}{l}\text { Dec. } \\
\text { week } 2\end{array}$ & $\begin{array}{l}\text { Dec. } \\
\text { week } 3\end{array}$ & $\begin{array}{l}\text { Dec. } \\
\text { week } 4\end{array}$ & $\begin{array}{l}\text { Jan. } 1 \\
\text { week }\end{array}$ & $\begin{array}{l}\text { Jan. } 2 \\
\text { week }\end{array}$ & $\begin{array}{l}\text { Jan. week } \\
3\end{array}$ & $\begin{array}{l}\text { Jan week. } \\
4\end{array}$ & $\begin{array}{l}\text { Feb. } \\
\text { week } 1\end{array}$ & $\begin{array}{l}\text { Feb. week } \\
2\end{array}$ & Feb. week 3 \\
\hline 733 & 2021 & 4559 & 6049 & 6186 & 6902 & 11177 & 10151 & & & \\
\hline
\end{tabular}

\section{Conclusion}

Comparing $\operatorname{mean}_{(\mathrm{A})}$ and that of $\operatorname{mean}_{(\mathrm{B})}$, clearly, we observe that the rate of spread during the second wave is far greater than that during the first wave.

\section{Recommendation}

Measures have to be seriously put in place so as to curtail the sporadic spread. In doing this all the safety protocols have to be strictly adhered to. The government has to make provisions for enforcing that those laws and protocols so as to put a necessary check on the pandemic.

\section{References}

[1] I. Ahmad and F. A. Rathore, Neurological Manifestations and Complications of COVID-19: A Literature Review. Preprints 2020 .

[2] V. Clemente, P. D'Arcy and M. Bazzaro, Deubiquitinating Enzymes in Coronaviruses and Possible Therapeutic Opportunities for COVID-19. Int. J. of. Mol. Sci. 2020, 21, 1-17.

[3] S. K. Reddy, S. Mazhar and R. Lencucha, The financial sustainability of the World Health Organization and the political economy of global health governance: a review of funding proposals. Glob. And Health. 2018, 14, Article number 119.

[4] Y. Liu, A. A. Gayle, A. Wilder-Smith and J. Rocklöv, The reproductive number of COVID-19 is higher compared to SARS coronavirus. Int. Soc. of Tra. Med. 2020, 1-4.

[5] R. Piyush, K. Rajarshi, R. Khan andS. Ray, Convalescent plasma therapy: a promising coronavirus disease 2019 treatment strategy. Open Biol. 2020; 10 (9): 200174. doi: 10.1098/rsob.200174.

[6] M. P. Lythgoe and P. Middelton, Ongoing Clinical Trials for the Management of the COVID-19 Pandemic. Trends Pharmacol Sci 2020, 41, 363-382.
[7] E. Wehling, Framing-Manual. Unser gemeinsamer, freierRundfunk ARD. University of California, Berkley, USA, 2019, Page 1-89.

[8] A. D. Koon, B. Hawkins and S. H. Mayhew, Framing and the health policy process: a scoping review. Health Pol. And P1. 2016, 31, 801-816.

[9] J. A. Krosnick and B. MacInnis, Frequent Viewers of Fox News Are Less Likely to Accept Scientists' Views of Global Warming. Wo. Inst. for the Env. at Stan. Uni. 2010, 1-12.

[10] Z. G. Li, Z. Zheng, S. Qiu, J. Luo, C. Ye, S. Zhu and N. Zhong, Clinical Characteristics of Coronavirus Disease 2019 in China. N Engl J Med. 2020, 30, 1708-1720.

[11] Protective and Environmental Measures. Emerging Infectious Diseases, 26 (5), 967-975. https://dx.doi.org/10.3201/eid2605.190994.

[12] World Health Organization. Laboratory testing for 2019 novel coronavirus $(2019-\mathrm{nCoV})$ in suspected human cases, Interim guidance, 17 January 2020. Int. Guid. 2020, 1-7.

[13] Severe Outcomes Among Patients with Coronavirus Disease 2019 (COVID-19) - United States, February 12 - March 16, 2020.

https://www.cdc.gov/mmwr/volumes/69/wr/mm6912e2.htm.

[14] Provisional Death counts for Coronavirus Disease (COVID19): https://www.cdc.gov/nchs/nvss/vsrr/COVID19/index.htm.

[15] U.S. Influenza Surveillance System: Purpose and Methods. https://www.cdc.gov/flu/weekly/overview.htm\#Hospitalization.

[16] The COVID Tracking Project. US Historical Data. https://covidtracking.com/data/us-daily.

[17] COVID Surg Collaborative. Elective surgery cancellations due to the COVID-19 pandemic: global predictive modelling to inform surgical recovery plans. Wil. Onl. Libr. 2020, 1-10.

[18] https://www.hygeiahmo.com/fight-against-covid-19/.

[19] (https://COVID19.ncdc.gov.ng/contact/).

[20] https://ncdc.gov.ng/news/276/end-of-year-travel-advisory-oncovid-19.

[21] https://nitp.ncdc.gov.ng/onboarding/guidelines. 